\title{
進行喉頭癌および再発例に対する垂直喉頭部分切除術
}

\author{
小 川 徹 也·鈴 木 政 博·鈴 木 秀 典・長谷川 泰 久
}

\section{Vertical Partial Laryngectomy for Advanced and Recurrent Laryngeal Cancers}

\author{
Tetsuya Ogawa, Masahiro Suzuki, Hidenori Suzuki \\ and Yasuhisa Hasegawa
}

\begin{abstract}
The preservation of larynx function is a particularly important challenge in head and neck cancer therapy. We considered adaptation and problems associated with vertical partial laryngectomies in particular in reviewing the results of functional preservation operations until present.

Vertical partial laryngectomies show a high incidence of complications, such as postoperative fistulation, but in most cases the complications were minor in nature.

There were no cases with grave complications, such as postoperative hemorrhaging or total laryngectomies with necrosis of the remnant cartilage.

We came to the conclusion that the vertical partial laryngectomy operative method could be safely performed even for a recurrence after radical cure treatment.
\end{abstract}

Key words：垂直喉頭部分切除術，進行喉頭癌

$$
\text { は じめ に }
$$

頭頸部癌の治療において機能温存，特に喉頭機能の温存 は重要な課題である，外科治療における喉頭機能の温存に は喉頭部分切除術が多く行われる。声門癌では垂直喉頭部 分切除術 (vertical partial laryngectomy, VPL) が最 も一般的な術式である。さらに，両側声帯の病変を有する 例には輪状軟骨上喉頭部分切除術 (supracricoid partial laryngectomy，SPL）がある。さらに声門上癌には声門 上水平喉頭部分切除術 (partial horizontal supraglottic laryngectomy, HSL) が行われる.VPL と SPL, さら にHSLの利点は，永久気管口を設けることなく，呼吸と 発声機能，さらに下気道の保護を獲得することにある。こ れらの術式は機能的に優れている反面，切除範囲が限定さ れる上に，再建術式が喉頭全摘と比べて複雑となるため, 合併症が高くなる。また腫瘍に対する安全域の設定に苦慮 することもある。

$\mathrm{T} 1 / 2$ の喉頭癌に対して放射線治療が主に用いられてい るという本邦の状況，さらに機能温存治療への要望の高ま りを考えると, $\mathrm{T} 1 / 2$ 照射後再発例に対しても機能温存術 式の適応は今後より多くの症例で考慮されることとなるで あろう。さらにT3といった進行例に扔いても，機能温存 治療の認識の高まりとともに適応症例が増えてくることが 予測される。 それゆえ機能温存術式のこれまでの詳細な検 討が必要となり，その結果をふまえた上での，個々の症例 に応じた様々な術式の幅広い選択が必要とされる。
今回われわれは，これまでに行った喉頭癌に対する機能 温存手術例の治療成績を検討するため, 特に垂直喉頭部分 切除術の適応と問題点について考察した。

\section{対象と方 法}

対象は1999年から2006年の間に愛知県がんセンター頭頸 部外科に扔いて垂直喉頭部分切除術を施行した喉頭癌20例 である．年齢は43歳から83歳で，平均年齢は62.5歳であり， 性別は男性が19例で，女性が1例であった。治療歴は未治 療が 1 例, 化学放射線療法（導入化学療法：シスプラチン, $5 \mathrm{FU}$ 治療後放射線治療30Gy で効果判定）効果不良が 2 例, 化学放射線療法後再発が 1 例, 放射線根治治療後再発が 16 例であった。その放射線照射線量は30Gy から70Gyで, 中 央值は66Gyであった。手術療法時の病期は I 期が 13 例, II 期が 5 例， III 期が 1 例， IVA 期が 1 例であった。これ らの症例の術式と治療成績について検討した。

結果

1) 術式 :

前側垂直喉頭部分切除術が14例で, 拡大前側垂直喉頭部 分切除術が 6 例であった. 声門 T3N0M0症例と, 声門上 部 rT4N2bM0症例で頸部郭清術を追加した。喉頭の再建 には全ての症例で有茎前頸部皮弁を用いた，拡大前側垂直 喉頭部分切除術の症例の内訳は rTlaN0M0が 3 例, T2N0M0が 1 例, T3N0M0が 1 例, rT4N2bM0が 1 例で あった。

愛知県がんセンター中央病院 頭頸部外科

Department of Head and Neck Surgery, Aichi Cancer Center 
2 ）外㾇化の有無, 喉頭機能及び嚥下機能 :

1. 外瘻化の有無:

20例中 4 例で，喉頭皮膚瘻を作製し二期的に閉鎖を試み た. 1 例は糖尿病を合併し創傷治癒の遷延が予測されたた め施行した。 2 例は73歳, 80歳と高齢であったため施行し た。その他の 1 例は化学照射療法後再発症例で創傷治癒の 遷延が予測されたため施行した。この症例は頸部郭清側に 大胸筋弁を挿入することを追加し，喉頭皮膚瘻を作製する こととともに頸部感染と頸動脈破裂の予防を目的とした術 後合併症に備える手術とした。 その他の16例は一期的に喉 頭を閉鎖した。

2. 喉頭機能および嚥下機能：

(喉頭機能)

対象症例20例中, 喉頭皮膚瘻を閉鎖していない 1 例を除 いた19例で検討した。 19例中 1 例でワンウェイバルブ装着 を要したが発声は可能であった。その他の18例は気管口の 閉鎖もできて発声可能である。呼吸機能，下気道の保護は 保たれている。

(蟮下機能)

19例では嚥下障害等は認めず，常食の摂取が可能である.

\section{3) 合併症 :}

創部合併症は一期再建症例16例中，11例（69\%）で㾇孔 形成が認められた。 その多くは保存的治療で治癒する小瘻 孔または膿瘍であった。しかしながら11例中 5 例（31\%） で再手術を要した４例は局所麻酔下に，1例は全身麻酔 下に手術が必要であった。

二期再建症例 4 例の中で 2 例に残存軟骨膜炎を認めた。 この 2 例で創傷治癒の遅延を認めたが保存的に改善し，1 例は喉頭皮膚瘻を局所麻酔化に閉鎖できた。

術後出血や残存軟骨炎の悪化に伴う喉頭全摘術などは認 めなかった。
4) 予後：

観察期間の中央值が30ケ月で，他病死が 1 例に認められ た.19例は再発を認めず生存中である。

\section{考察}

今回のわれわれの検討では，垂直喉頭部分切除術は術後 瘻孔形成などの合併症の頻度は高いが，その多くは保存的 な処置で対応が可能で小合併症が多い結果であった。術後 出血や残存軟骨炎の悪化に伴う喉頭全摘術などといった重 篤な合併症は一例も認めなかった。放射線治療後再発症例 に対する垂直喉頭部分切除術の報告は少ない ${ }^{1)}$.われわれ の検討では20例中放射線治療後の症例が19例であったこと， またその多くが放射線根治照射後症例であったことを考え ると, 本術式はこのような放射線治療後症例にも比較的安 全に行える術式であると考えることができる。

喉頭機能温存率は喉頭皮膚㾞を閉鎖していない 1 例を除 いた19例中 1 例がワンウェイバルブを装着し発声を行って いるため $94.7 \%$ （18/19例）となる。これら結果から，わ れわれの施設における垂直喉頭部分切除術の機能面におけ る結果は良好であると考えられる。また嚥下機能の検討か らも，19例では嚥下障害等は認めず，常食の搔取が可能で ある。嚥下機能面からも垂直喉頭部分切除術の結果は良好 であると考えられる。

垂直喉頭部分切除術の適応の多くは $\mathrm{T} 1 / 2$ 声門癌である と考えられる。しかしながら，その適応は腫瘍が解剖学的 にどの部位に存在するのかでより正確に決められる。前方 に関しては，対側前連合にわずかに浸潤しているか一側に 限局している症例は適応の限界となる。前連合を大きく超 えて対側の声帯に浸潤するような症例では $\mathrm{SPL}^{2)}$ などの 適応となる。側方では声帯傍間隙への浸潤のため T3とな る症例までが本術式においては，甲状軟骨を合併切除する ため, 通常の適応の限界になると考えられる。T4a 症例で も，甲状軟骨への浸潤が限局的で前頸筋をマージンとして 切除できるのなら適応となる場合もある (図 1). 後方浸

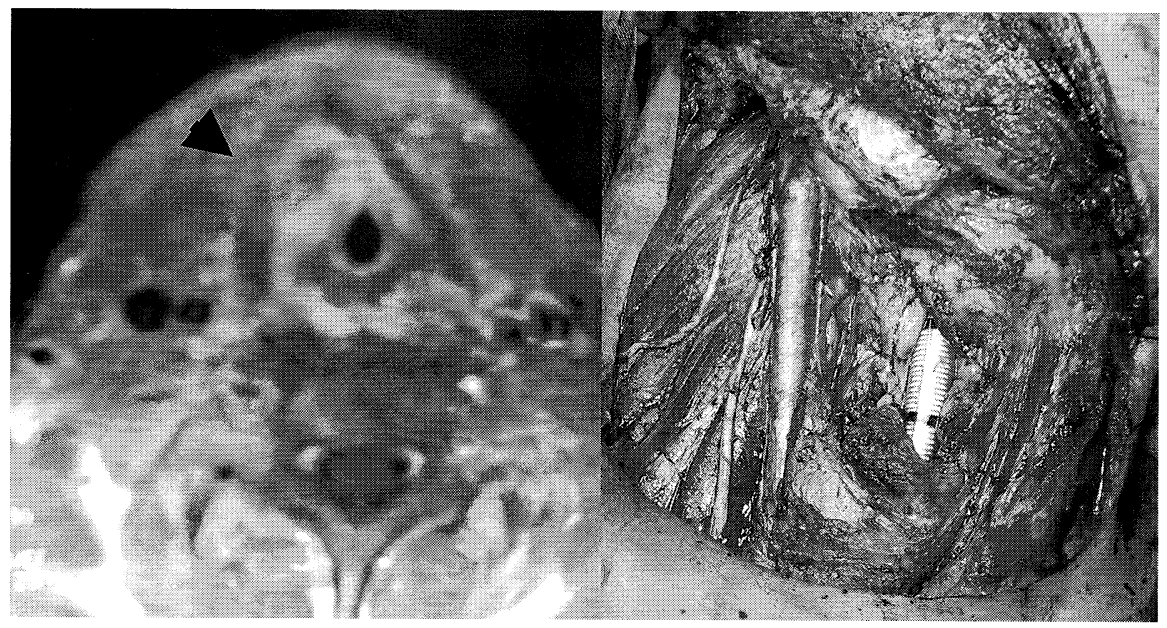

図 1 側方限界：限局性の甲状軟骨浸潤 T4a 例（矢印は浸潤部） 


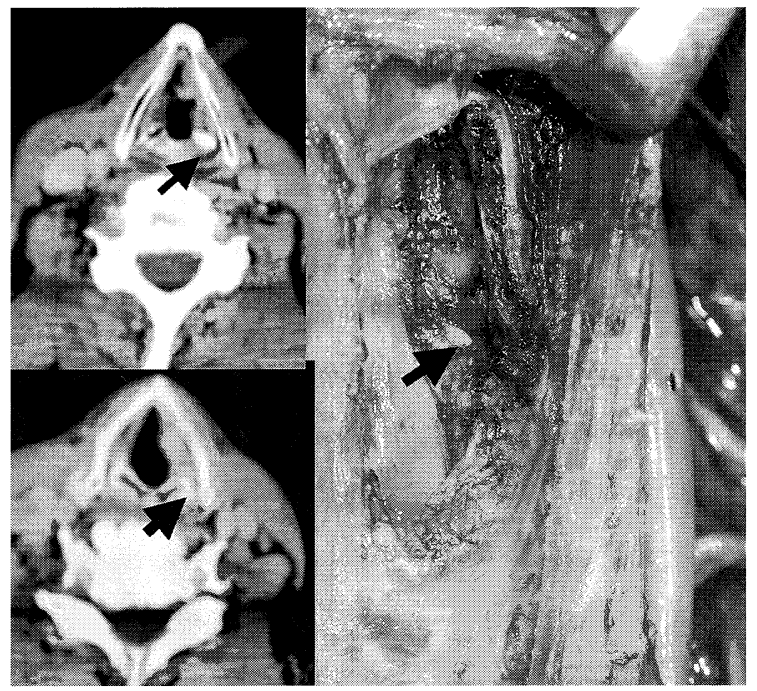

図 2 後方限界：輪状披裂関節に浸潤していない T3 症例（矢印は輪状披裂関節）

潤は披裂部に浸潤があるが輪状披裂関節に浸潤していない 症例までが適応となる（図 2)。輪状披裂関節に浸潤がみ られる症例は輪状軟骨も切除する必要があり, 本術式の適 応とはならない.われわれの経験ではこのような浸潤性の 広範囲切除例では垂直部分切除の拡大型の術式として, Pearson 法 $^{3)}$ が適応となると考える。しかしながら， Pearson 法では永久気管口が作製されることとなる。本 術式を回避しつつも, さらに輪状軟骨半側切除を要する例 では，硬性再建を併用した遊離組織移植による再建法の開 発が今後必要と考える。上方は一側の仮声帯までの浸潤の みの症例なら適応となる。下方ではわずかな表在性粘膜浸 潤の病変は声門下粘膜の切除を行うことで対応が可能であ るかと考える。

本検討では放射線根治治療後症例も多く含まれている. しかしながら重篤な合併症は認めなかった，放射線治療後 の軟骨壊死や骨髄炎の頻度は組織学的には $27 \%$ にぶとの 報告4) がある。われわれの検討では $2 / 20$ 例（10\%）であっ た. 喉頭部分切除術では軟骨壊死は対応に苦慮する合併症 であり，その対策が今後の重要な課題であると思われるが, 術前に糖尿病を合併する症例や高齢者, 化学照射療法後再 発症例などのハイリスクと思われる症例には，あらかじめ 二期的再建を考慮した喉頭皮膚瘻孔を作製しておき後日閉 鎖することもよい方法かと考える。

年齢に関しては，83歳の高齢者にも本術式が行われてお り，術後合併症も生じなかった，高齢者に対しても垂直喉 頭部分切除術の報告はみられるが5), これら高齢者に対し
ては二期的再建等を考慮し, 確実な創傷治癒を来してから 安全に喉頭皮膚瘻を閉鎖することが必要である.

予後については, 本術式施行後再発症例は 1 例も認めな かった、様々な報告では局所再発，遠隔再発等がみられる ようであるが6)，われわれの結果では現在までのところ良 好な結果である。ささらに仮に今後再発を来しても, 早期発 見の上, 残存喉頭全摘術を行うことで救済も可能である.

垂直喉頭部分切除術は根治治療後再発でも, 安全に施行 できる術式であると考えられた。高齢者, 化学放射線治療 後再発症例, 糖尿病合併症例などのハイリスク症例に対し ては，予め喉頭皮膚㾞を作製しておくことで合併症の軽減 を期待することができる。

$$
\text { 文献 }
$$

1) Mooney WW, Cole I, Albsoul $N$ et al : Pearson SA. Salvage vertical partial laryngectomy for radiation failure in early glottic carcinoma. ANZ J Surg. 72 : 746 749, 2002.

2) Laccourreye O, Laccourreye L, Garcia D et al: Vertical partial laryngectomy versus supracricoid partial laryngectomy for selected carcinomas of the true vocal cord classified as T2N0. Ann Otol Rhinol Laryngol. 109 : 965 971, 2000.

3) Pearson BW, DeSanto LW, Olsen KD et al : Results of near-total laryngectomy. Ann Otol Rhinol Laryngol. 107 : 820 825, 1998.

4) Keene M, Harwood AR, Bryce DP et al : Histopathological study of radionecrosis in laryngeal carcinoma. Laryngoscope. 92: 173 180, 1982.

5）鬼塚哲郎, 海老原敏, 大山和一郎ほか：高齢者にお ける喉頭垂直部分切除術の検討. 頭頸部腫瘍 29 : 23 26, 2003.

6) Laccourreye O, Gutierrez-Fonseca R, Garcia D et al : Local recurrence after vertical partial laryngectomy, a conservative modality of treatment for patients with Stage I-II squamous cell carcinoma of the glottis. Cancer. $15: 2549 \sim$ 2556, 1999.

別刷請求先 $=464-8681$ 名古屋市千種区鹿子殿 1 番 1 号 愛知県がんセンター中央病院 頭頸部外科 長谷川泰久 